\title{
KEEFEKTIFAN IMPLEMENTASI PENDEKATAN SAINTIFIK DENGAN METODE INKUIRI DAN PROBLEM-BASED LEARNING DITINJAU DARI MINAT SISWA
}

\author{
Arnoldus Fransiskus Bai ${ }^{1)}$ Dyah Respati Suryo Sumunar ${ }^{2)}$ \\ Pendidikan Geografi, Program Pascasarjana, Universitas Negeri Yogyakarta ${ }^{2)}$ \\ arnoldusfransiskus6@gmail.com ${ }^{1)}$, respatisuryo@yahoo.com ${ }^{2}$
}

Abstrak

Penelitian ini bertujuan untuk mengungkapkan kefektifan implementasi pendekatan saintifik dengan metode inkuiri dan problem-based learning ditinjau dari minat siswa terhadap hasil belajar geografi kelas X SMA Negeri di Kabupaten Ngada. Metode penelitian yang digunakan adalah eksperimen. Penelitian dilaksanakan pada dua kelompok. Kelompok eksperimen 1 adalah kelompok sampel yang menggunakan metode inkuiri, kelompok eksperimen 2 adalah kelompok sampel yang menggunakan metode problem-based learning. Pengambilan sampel dilakukan dengan teknik cluster sampling. Analisis data menggunakan analisis deskriptif dan inferensial analisis varian (anava). Simpulan penelitian ini adalah, (1) Tidak terdapat perbedaan yang signifikan dari pembelajaran metode inkuiri dan metode problem- based learning terhadap hasil belajar geografi. (2) Tidak terdapat perbedaan yang signifikan dari tingkat minat belajar siswa terhadap hasil belajar geografi; (3) Pada masing-masing metode pembelajaran tidak terdapat perbedaan dari tingkat minat belajar terhadap hasil belajar geografi. (4) Pada masing-masing kategori, tidak ada perbedaan minat belajar dengan metode pembelajaran terhadap hasil belajar geografi.

Kata kunci: inkuiri, problem-based learning, minat siswa

\section{THE EFFECTIVENESS OF THE IMPLEMENTATION OF THE SCIENTIFIC APPROACH WITH THE INQUIRY METHOD OF LEARNING AND THE PROBLEM-BASED LEARNING IN TERMS OF THE STUDENTS' INTEREST}

\author{
Arnoldus Fransiskus Bai ${ }^{1)}$ Dyah Respati Suryo Sumunar ${ }^{2)}$ \\ Pendidikan Geografi, Program Pascasarjana, Universitas Negeri Yogyakarta ${ }^{2)}$ \\ arnoldusfransiskus6@gmail.com ${ }^{1)}$, respatisuryo@yahoo.com $^{2}$
}

\begin{abstract}
This study aims to reveal the effectiveness of the implementation of scientific approaches with inquiry methods and problem-based learning in terms of student interest in the results of geography class X SMA Negeri Ngada. The study employed the experimental method. It involved two groups, namely experimental group 1 and experimental group 2. Experimental group 1 was the sample group learning through the inquiry method, while experimental group 2 was the one learning through the problem-based learning method. Two classes were selected as the sample, namely experimental group 1 and experimental group 2. The sample was established by means of the cluster sampling technique. The data were primary data collected through questionnaires and learning achievement tests. The data analysis techniques were the descriptive analysis and the inferential analysis of variance (ANOVA). The conclusions of the study are as follows. (1) There is no significant difference between the learning through the inquiry method and that through the problem-based learning in terms of the geography learning achievement. (2) There is no significant difference in the students' learning interest level in terms of the geography learning achievement. (3) In each learning method, there is no significant difference in the learning interest level in terms of the geography learning achievement. (4) In each learning interest category, there is no difference in the learning methods in terms of the geography learning achievement.
\end{abstract}

Keywords: inquiry learning, problem-based learning, students' interest 


\section{Pendahuluan}

Menjadi guru kreatif, profesional dan menyenangkan dituntut untuk memiliki kemampuan mengembangkan pendekatan dan memilih metode pembelajaran yang efektif, hal ini penting terutama untuk menciptakan iklim pembelajaran yang kondusif dan menyenangkan (Mulyasa, 2010, p. 95).

Proses pembelajaran mempunyai pengertian kegiatan nyata yang mempengaruhi anak didik dalam situasi yang memungkinkan terjadinya interaksi antara guru dengan siswa, siswa dengan sisiwa, siswa dengan lingkungan belajarnya. Umumnya, kegiatan pembelajaran mencakup, kegiatan awal dan pembukaan, kegiatan inti atau pembentukan kompetensi atau karakter serta kegiatan akhir atau penutup.

Menurut Hughes, (2003, pp. 465-466) ada beberapa perinsip penting dalam pendidikan:

Siswa belajar melalui aktivitas yang menumbuhkan daya dorong (motif) untuk belajar dari kecenderungan naluriah, dengan demikian guru harus mengajar dengan memberi siswa lingkup yang menarik kecenderungan naluriah mereka. (1) siswa belajar dengan memahami secara samar keseluruhan yang kompleks yang kemudian akan mereka analisis. Karena itu guru harus mengajar, tidak dengan membangun unsur unsur terpisah sendiri sendiri tetapi dengan mengemukakan keseluruhan dan membantu siswa untuk menemukan unsurunsur dalam latar ilmiah mereka. (2) metode dan kecepatan belajar tergantung pada kualitas mental setiap individu. Sebagian kualitas mental kurang lebih sama pada semua anak, dan karennya dimungkinkan untuk memikirkan beberapa metode umum pengajaran yang dapaat dgunakan bagi peserta didik, namun secara detal peserta didik berbeda satu sama lain secara fisik, tempramental, maupun intelektual, sehingga perlu menggunakan metode pembelajaran yang bisa memenuhi kebutuhan khusus peserta didik. (3) siswa belajar untuk mengembangkan kekuatan penuh mereka hanya dalam lingkungan sosial, karena itu metode pembelajaran harus menyediakan beberapa tugas atau kegiatan untuk dikerjakan oleh peserta didik dalam kelompok.

Secara konseptual kurikulum adalah suatu respon pendidikan terhadap kebutuhan masyarakat dan bangsa dalam membangun generasi muda bangsanya. Secara pedagogis kurikulum adalah rancangan pendidikan yang memberikan kesempatan untuk peserta didik mengembangkan potensi dirinya dalam suatu suasana belajar yang menyenangkan dan sesuai dengan kemampuan dirinya untuk memiliki kualitas yang diinginkan masyarakat dan bangsanya.

Berdasarkan fungsi dan tujuan pendidikan nasional maka pengembangan kurikulum haruslah berakar pada budaya bangsa, kehidupan bangsa masa kini, dan kehidupan bangsa dimasa mendatang. Perubahan Kurikulum 2013 disertai dengan cara menilai kompetensi peserta didik. Kompetensi yang dimaksud merupakan kemampuan melakukan unjuk kerja dengan pengetahuan keterampilan dan sikap yang sesuai.

Kurikulum 2013 dikembangkan dengan tujuan mewujudkan tujuan pendidikan nasional, yakni: berkembangnya potensi peserta didik agar menjadi manusia yang beriman bertakwa kepada Tuhan Yang Maha Esa, berakhlak mulia, sehat, berilmu, cakap, kreatif, mandiri dan menjadi dan menjadi warga negara yang demokratis serta bertanggung jawab. Pengembangan potensi peserta didik harus dikembangkan secara bertahap sesuai dengan perkembangan psikologi peserta didik sehingga pendidikan pada tingkat skolah dasar harus fokus pada pengembangan sikap dan perilaku.

Penerapan Kurikulum 2013 memerlukan perubahan paradigma pembelajaran, dimana peserta didik dilatih untuk belajar mengobservasi, mengajukan pertanyaan, mengumpulkan data, menganalisis (mengasosiasikan) data, dan mengkomunikasikan hasil belajar yang disebut pendekatan saintifik. Pendekatan ini perlu dilakukan untuk dapat mengembangkan kemampuan peserta didik untuk belajar mandiri dan berpikir kreatif, Untuk dapat menerapkan pembelajaran sesuai dengan tuntutan kurikulum 2013 guru perlu memiliki pengetahuan yang memadai tentang pendekatan saintifik.

Pendekatan saintifik dimaksudkan untuk memberikan pemahaman kepada peserta didik dalam mengenal, memahami berbagai materi menggunakan pendekatan ilmiah, bahwa informasi bisa berasal dari mana saja, kapan saja, tidak bergantung pada informasi dari guru (Gustin \& Suharno, 2015, p. 146). 
Selain metode pembelajaran, perlu dikembangkan juga media pembelajaran interaktif yang dipadukan dengan penerapan pendekatan saintifik, sehingga siswa dapat memperoleh pengetahuan melalui aktifitas mengamati, menanya, mencoba, menalar dan mengkomunikasikan hasilnya dengan demikian siswa ikut serta aktif dalam proses pembelajaran sehingga tidak hanya paham tentang konsep, namun juga mengerti realita atau faktanya di masyarakat. Melalui strategi ini, siswa tidak hanya memiliki nilai yang baik disekolah namun juga memiliki prilaku yang baik sesuai aturan dan hukum yang berlaku Candra, \& Masruri, 2015, p. 110).

Pemilihan metode pembelajaran perlu disesuaikan dengan karakteristik topik yang dipelajari, oleh sebab itu guru harus dapat menyusun rencana pembelajaran yang efektif dan efisien dengan pemikiran dan pertimbangan yang matang. Penggunaan metode yang tepat akan turut menentukan efektivitas dan efisiensi pembelajaran pembelajaran perlu dilakukan dengan sedikit ceramah dan metode metode yang berpusat pada guru, serta lebih menekankan pada interaksi peserta didik. Penggunaan metode yang bervariasi akan sangat membantu peserta didik dalam mencapai tujuan pembelajaran. Prinsip prinsip psikologis dalam pembelajaran harus diterapkan dengan cara tertentu: metode metode yang mengandalkan dorongan rasa takut jelas tidak baik; anak membutuhkan dorongan dan rangsangan kearah keberhasilan.

Pengalaman belajar di sekolah harus fleksibel, serta perlu menekankan pada kreativitas, rasa ingin tahu, bimbingan dan pengarahan ke arah kedewasaan. Metode pembelajaran harus dipilih dan dikembangkan untuk meningkatkan aktivitas dan kreativitas peserta didik.

Pembelajaran dalam Kurikulum 2013 menggunakan penilaian autentik yang digunakan untuk menilai pengetahuan dan keterampilan peserta didik ditinjau dari penerapan pengetahuan dan keterampilan tersebut. Umumnya penilaian autentik dilakukan dengan menugaskan pada peserta didik untuk melaksanakan sebuah tugas dan guru menggunakan rubrik dalam menilai kinerja peserta didik penggunaan penilaian autentik diharapkan dapat membuat peserta didik untuk lebih giat belajar.
Guru memiliki peran yang sangat penting dalam menentukan kuantitas dan kualitas pengajaran yang dilaksanakanya, oleh sebab itu guru harus memikirkan dan memuat perencanaan secara seksama dalam meningkatkan kesempatan belajar bagi siswanya dan memperbaiki kualitas mengajarnya. Hal ini menuntut perubahan dalam penggunaan metode mengajar, strategi belajar mengajar, maupun sikap dan karakteristik guru dalam mengelola proses belajar mengajar, untuk memenuhi hal tersebut guru dituntut mampu mengelola proses belajar mengajar yang memberikan rangsangan kepada siswa sehingga ia mau belajar karena memang siswalah subjek utama dalam belajar.

Guru harus memiliki dua macam tanggung jawab berkenaan dengan masalah anak: pertama, guru harus memodifikasi metode pengajaran mereka untuk tetap sesuai dengan kondisi kelas yan meningkat, dan kedua, guru juga harus menjaga kelas agar lebih kecil untuk memungkinkan mereka mengadopsi metode individual dengan lebih sepenuh hati (Hughes, 2003, pp. 346-347)

Pembelajaran geografi yang dilaksanakan di SMA selama ini masih menggunakan pembelajaran yang hanya menggunakan metode tradisional seperti ceramah, diskusi latihan dan penugasan-penugasan. Metode pembelajaran yang masih klasikal, keterlibatan guru dalam pembelajaran masih dominan, dan siswa tidak terlibat secara langsung selama pembelajaran, siswa cenderung menerima apa saja yang diberikan guru, tidak termotivasi untuk turut aktif dalam pembelajaran dan tidak memiliki buku penuntun lain kecuali LKS yang disediakan dari sekolah, sehingga metode pembelajaran seperti ini tidak banyak memakai langkah penerapan pendekatan saintifik, respon siswa dalam pembelajaran cenderung lemah, dan kurang memahami konsep yang diberikan keadaan ini menyebabkan siswa kehilangan daya kritis dan daya kreatifnya untuk menghubungkan antara pengetahuan yang didapatkan dengan kehidupan nyata mengakibatkan minat belajar siswa rendah. Orientasi guru dalam melaksanakan pembelajaran lebih terfokus pada pencapaian target yang tinggi dalam penyampaian materi sehingga seringkali mengabaikan proses pemberdayaan aspek afektif dan psikomotrorik yang mengakibatkan belajar menjadi tidak 
bermakna, peserta didik akan kesulitan untuk memecahkan masalah.

Pemilihan metode pembelajaran terkait dengan karakteristik siswa dan materi yang dipelajari, jika siswa belum mampu berpikir kreatif dan inovatif, pembelajaran berbasis proyek akan sulit dilakukan. Pembelajaran berbasis masalah mungkin tidak membutuhkan inovasi yang tinggi, nampun membutuhkan keterampilan berpikir kreatif, oleh karena itu kemampuan berpikir kreatif dan inovatif harus dilakukan sedini mungkin. (Sani, 2014, p.79)

Metode yang sesuai dengan pendekatan pembelajaran saintifik antara lain: pembelajaran berbasis inkuiri, pembelajaran penemuan (discovery learning), pembelajaran berbasis masalah (problem based learning), dan pembelajaran berbasis proyek (project based learning) dan metode lain yang relevan (Sani, 2014, p. 76).

Inkuiri bukan hanya metode atau pendekatan pembelajaran, melainkan juga sebuah filosofi belajar. Siswa dilatih untuk bertanya kemudian menentukan strategi atau cara menjawab, menganalisis dan akirnya menemukan jawabaan dari pertanyaanya.

Inquiry juga dapat menjadikan siswa yang pasif dalam menerima pengetahuan untuk menjadi siswa yang aktif dan mencipta pengetahuan, yang juga mencerminkan proses berpikir yang dapat diterapkan untuk berbagai situasi dan bidang studi (Johnson, 2010, p. 163).

Beberapa penelitian dilakukan seperti disampaikan Simsek \& Kabapinar, (2010, p. 190) yang menyimpulkan bahwa, inkuiri sebagai serangkaian proses yang saling terkait dimana para ilmuwan dan mahasiswa mengajukan pertanyaan tentang alam dan menyelidiki fenomena; dalam melakukannya, siswa memperoleh pengetahuan dan kemudian mengembangkan pemahaman yang kaya akan konsep.

Penelitian yang dilakukan Dostál (2015, p. 79) juga mengemukankan bahwa Instruksi berbasis inkuiri adalah kegiatan guru dan murid yang difokuskan pada pengembangan pengetahuan, keterampilan dan sikap yang didasarkan pada kognisi aktif dan relatif individu realitas yang oleh murid yang belajar dirinyanya sendiri dan bagaimana siswa mengeksplorasi.
Pendekatan inkuiri memang tidak dapat dipisahkan dari pendekatan pemecahan masalah, untuk menerapkan pendekatan ini dosen guru atau pendidik harus berpikir dan berprilaku memfasilitasi peserta didik untuk dapat mengidentifikasi apa yang akan dipelajari. Pendidik membantu siswa dalam membuat pertanyaan, menentukan strategi mengumpulkan informasi dan mengolah informasi. Pendekatan ini memerlukan pendidik yang kreatif dalam pembelajaran dan bekerja dengan rencana yang baik.

Siswa yang belajar dengan menerapkan inkuiri dalam ilmu sosial dapat melakukan aktivitas: (1) mengajukan pertanyaan untuk memperoleh informasi dan memeriksa isu yang relevan; (2) mengeksplorasi dan memeriksa nilai nilai dan pandangan orang lain; (3) memikirkan cara orang mengambil keputusan dan berpartisipasi dalam tindakan sosial; (4) melakukan refleksi dan mengevaluasi pemahaman.

Lebih lanjut pembelajaran berbasis inkuiri memberikan kesempatan kepada siswa untuk: (1) mengembangkan keterampilan yang dibutuhkan untuk hidup; (2) belajar menangani permasalahan; (3) berhadapan dengan tantangan dan perubahan untuk memahami sesuatu; dan (4) mengembangkan kebiasaan mencari solusi permasalahan.

Pembelajaran berbasis masalah merupakan sebuah pendekatan pembelajaran yang menyajikan masalah kontekstual sehingga merangsang peserta didik untuk belajar (Daryanto, 2014, p. 29)

Menurut Kementerian Pendidikan dan Kebudayaan (2013, p. 187), yang mengartiakn bahwa pembelajaran berbasis masalah merupakan pembelajaran yang menyajikan masalah kontekstual sehingga merangsang peserta didik untuk belajar.

Menurut Graaff \& Kolmos, (2003, p. 658). Pembelajaran berbasis masalah adalah pendidikan mendekati dimana masalahnya adalah startingpoint yang dari proses pembelajaran. Jenis masalah tergantung pada organisasi tertentu, biasanya masalah didasarkan pada kehidupan nyata masalah yang telah dipilih dan diedit untuk memenuhi tujuan pendidikan dan kriteria namun, juga bisa menjadi masalah hipotetis.

Meskipun peran guru dalam pembelajarn yang berbasis masalah kadang kadang juga melibatkan, mempresentasikan dan men- 
jelaskan berbagai hal kepada siswa tetapi lebih sering memfungsikan diri sebagai pembimbing dan fasilitator sehingga siswa dapat belajar untuk berpikir dan menyelesaikan masalahnya sendiri (Arends, 2007, pp. 45-46).

Penelitian Celika, Onderb, \& Silaya. (2011) mengemukakan bahwa Problem Based Learning menjadi metode yang memiliki manfaat lain-lain seperti menentukan masalah, menyelidiki penyebab mereka, hipotesa tentang penyebab, pengujian hipotesis, memperoleh informasi, menentukan target belajar, mengembangkan pemecahan masalah keterampilan, dan menggunakan informasi yang diperoleh di setiap tahap kehidupan.

Westwood (2008, p. 31) mengutip dari Similarly, (2001, p. 3). bahwa belajar melalui pemecahan masalah mungkin jauh lebih efektif daripada metode didaktik tradisional belajar dalam menciptakan pemahaman pengetahuan siswa yang berguna di masa depan".

Selain metode yang digunakan guru dalam mengajar, keberhasilan belajar siswa juga tidak terlepas dari minat belajar siswa. Menurut Slameto (2003, p. 57) minat adalah kecenderungan yang tetap untuk memperhatikan dan mengenang beberapa kegiatan. Minat sangat besar pengaruhnya terhadap belajar, karena bila materi pelajaran yang diberikan tidak sesuai dengan minat siswa, maka siswa tidak akan belajar dengan baik.

Minat belajar menurut Nelva (2010, pp. 136-1137) merupakan kecenderungan jiwa (afektif), perhatian seseorang dalam proses perubahan perilaku kearah positif sehingga seseorang menjadi termotivasi dan tumbuh rasa senangnya terhadap proses perubahan perilaku tersebut,

Perlunya minat belajar tidak hanya berarti bahwa seseorang memiliki minat untuk belajar tentang sesuatu. Ini juga berarti bahwa ketika seseorang memiliki minat pada sesuatu menjadi mudah dan bahkan menyenangkan untuk belajar tentang topik itu.

Ketertarikan pribadi berarti membawa siswa ke lingkungan belajar. Sebagai contoh, beberapa siswa datang ke kelas sains mereka sudah tertarik pada materi pelajaran, sedangkan yang lainnya tidak. Sebaliknya, situasional ini diperoleh ketika individu berpartisipasi dalam lingkungan belajar misalnya, beberapa pembelajaran lingkungan yang lebih memotivasi daripada yang lain Hong \& Siegler (2011, p.3)
Selain minat belajar pemilihan metode pembelajaran yang tepat sangat dubutuhkan agar mampu mengubah paradigma pembelajaran dari siswa sebagai obyek/sasaran pembelajaran menjadi subyek pelaku dari proses pembelajaran. Strategi pembelajaran harus mampu mengikutsertakan semua siswa untuk mendapatkan peran, mampu mengembangkan kemampuan dasar siswa dan sikap positif siswa sehingga proses belajar mengajar menjadi lebih menarik, menantang, menyenangkan dan mengatifkan semua aspek dari dalam diri siswa.

Pembelajaran dengan metode inkuiri dan problem-based learning dalam pendekatan saintifik di SMA Negeri Kabupaten Ngada terutama di SMA Negeri I Soa dan SMA Negeri I Golewa diharapkan dapat memberikan hasil yang baik karena metode dan pendekatan ini merupakan penyajian yang dilakukan oleh siswa sendiri yang diharapkan berhasil dalam meminimalkan kesalahan yang dialami siswa dalam menyelesaikan soal geografi, serta dapat menumbuh kembangkan potensi kemandirian siswa dalam belajar. Untuk itu peneliti bermaksud meneliti keefektivan antara metode-metode pembelajaran tersebut dalam penerapan pendekatan saintifik untuk meningkatkan hasil belajar geografi.

Berdasarkan uraian yang telah disampaian, penelitian ini bertujuan untuk mengungkapkan kefektifan implementasi pendekatan saintifik dengan metode inkuiri dan problem-based learning ditinjau dari minat siswa terhadap hasil belajar geografi kelas $\mathrm{X}$ SMA Negeri di Kabupaten Ngada.

\section{Metode}

Penelitian menggunakan Rancangan faktorial 2 x 3 penelitian yang diterapkan adalah Rancangan Eksperimen Semu (Quasi). Penelitian ini dilaksanakan pada dua kelompok yaitu pada kelompok eksperimen 1 dan kelompok eksperimen 2. Kelompok eksperimen 1 adalah kelompok sampel yang diberikan perlakuan khusus dalam kegiatan pembelajarannya, yaitu pembelajaran dengan menggunakan metode inkuiri, sedangkan kelompok eksperimen 2 adalah kelompok sampel yang digunakan sebagai pembanding yang dalam kegiatan pembelajarannya menggunakan metode problem-based learning. variabel kontrol adalah minat siswa yang dibedakan menjadi 
tiga kategori yaitu tinggi, sedang, rendah. Variabel terikatnya adalah hasil belajar siswa.

Penelitian ini dilaksanakan di dua SMA Negeri di kabupaten Ngada, SMA Negeri I Soa yaitu pada kelas Xa sebagai kelas eksperimen 1 yang menggunakan metode pembelajaran inkuiri dan SMA Negeri I Golewa yaitu pada kelas Xd sebagai kelas eksperimen 2 yang menggunakan problem-based learning. Penelitian dilakukan pada bulan Maret sampai dengan bulan April, periode semester Genap Tahun Ajaran 2015/2016.

Populasi dalam penelitian ini adalah seluruh siswa kelas X SMA Negeri 1 Golewa dan SMA Negeri 1 Soa Kabupaten Ngada pada periode semester genap Tahun Ajaran 2015/2016. Adapun Pengambilan sampel dilakukan dengan cara cluster sampling. Tekniknya dengan membedakan populasi menjadi dua bagian tiap bagian akan dipilih secara random salah satu kelas yang akan di pakai sebagai sampel. Kelas yang digunakan untuk kelas eksperimen menggunakan kelas yang sudah ada, tanpa randomisasi secara individu, kelas yang diambil sebagai sampel adalah sebagai berikut.

Tabel 1. Sampel Penelitian

\begin{tabular}{|c|l|c|c|}
\hline No & Nama Sekolah & Jumlah Kelas X & Sampel \\
\hline 1 & $\begin{array}{l}\text { SMA Negeri I } \\
\text { Soa }\end{array}$ & A,B,C,D,E,F,G,H & XA \\
\hline 2 & $\begin{array}{l}\text { SMA Negeri I } \\
\text { Golewa }\end{array}$ & A,B,C,D,E,F,G,H & XD \\
\hline
\end{tabular}

Adapun variabel bebas atau independent variable dalam penelitian ini adalah Metode pembelajaran. Metode pembelajaran dalam penelitian ini ada dua yaitu pembelajaran inkuiri dan problem-based learning.. Variabel terikat dalam penelitian ini adalah hasil belajar siswa pada materi hidrosfer, sedangkan variabel kontrol dalam penelitian ini adalah minat siswa yang dikategorikan menjadi tinggi, sedang, dan rendah.

Teknik pengumpulan data yang digunakan dalam penelitian ini adalah dokumentasi, metode tes dan metode angket. Dokumentasi digunakan untuk data awal yaitu nama dan nilai ulangan harian mata pelajaran geografi. Pengumpulan data ini dimaksudkan untuk mengetahui kemampuan siswa tentang hasil belajar geografi dari sampel yang terpilih sebelum dikenai perlakuan. Metode tes digu- nakan untuk mengukur pemahaman konsep peserta didik, Tes diberikan sekali setelah pelaksanaan melalui metode pembelajaran. Angket digunakan untuk mengevaluasi hasil belajar pada aspek afektif.

Langkah penting dalam rangka mengumpulkan data adalah melakukan pengujian terhadap instrumen (alat ukur) yang akan digunakan, pengujian instrumen penelitian meliputi pengujian validitas isi dan reliabilitas. Pengujian validitas dan reliabilitas instrumen dilakukan dengan bantuan programer komputer yaitu statiscal product and service solutions (SPSS).

\section{Hasil Penelitian dan Pembahasan}

Uji Validitas isi soal tes, penilaian apakah instrumen tes hasil belajar geografi yang digunakan memiliki validitas isi yang tinggi, penulis mengkonsultasikan pada validator. Total 42 soal yang di periksa diperbaiki dan digenapkan menjadi 40.

Uji Reliabilitas soal tes, Pengujian reliabilitas dalam penelitian ini dilakukan dengan menghitung besarnya nilai Cronbach's Alpha dari instrumen penelitian. Apabila nilai Cronbach's CoefficientAlpha lebih besar dari 0,6, maka jawaban dari para responden pada kuesioner sebagai alat pengukur dinilai dinyatakan reliabel. Jika nilai Cronbach's CoefficientAlpha lebih kecil 0,6, maka dinyatakan tidak reliabel. Hasil uji coba 40 butir soal instrumen tes hasil belajar geografi terhadap 33 responden siswa SMA Negeri I Soa menunjukkan bahwa besarnya indek reliabilitasnya 0,835 dan terhadap 22 responden siswa SMA Negeri I Golewa Barat menunjukkan bahwa besarnya indek reliabilitasnya 0,948 . Oleh karena itu, butir soal tersebut reliabel dan layak dipakai untuk uji hasil belajar geografi

Hasil uji coba instrumen tes hasil belajar geografi menunjukkan bahwa dari 40 butir soal uji coba ada 7 butir soal yang tingkat kesukarannya diluar $0,3 \leq \mathrm{P} \leq 0,7$ yaitu nomor 1, 4, 8, 23, 36 dan 40. Selain 7 butir soal tersebut tingkat kesukarannya memenuhi persyaratan .

Daya Beda soal tes, Penelitian ini daya beda yang digunakan $r_{x y}>0,3$. Hasil perhitungan daya beda butir tes menunjukkan bahwa dari 40 butir soal yang diuji cobakan ada 7 butir soal yang tidak memenuhi kriteria 
Keefektifan Implementasi Pendekatan Saintifik ...

yaitu butir soal nomor $1,8,15,27,29,30$, dan 31. Selain 7 butir soal tersebut layak dipakai untuk tes hasil belajar.

Berdasarkan kriteria tingkat kesukaran dan daya beda butir soal yang digunakan, maka butir soal yang tidak memenuhi ada 12 butir soal yaitu nomor 1, 2 3, 4, 8, 15, 27, 29, 30, 31, 36 dan 40. Sedangkan butir soal yang dipakai dalam pengambilan data hasil belajar hanya 28 nomor yaitu nomor $5,6,7,9,10,11$, $12,13,14,16,17,18,19,20,21,22,23,24$, $25,26,28,32,33,34,35,37,38$, dan 39.

Uji Validitas Isi, Penilaian apakah angket minat belajar geografi yang digunakan memiliki validitas isi yang tinggi, penulis mengkonsultasikan pada validator. Dari 30 soal yang di periksa diperbaiki menjadi 20 soal yang layak

Uji Reliabilitas angket minat, Hasil uji coba 20 butir pernyataan angket minat belajar geografi terhadap 49 responden menunjukkan bahwa besarnya indeks reliabilitasnya 0,788 . Oleh karena itu, butir pertanyaan angket tersebut reliabel dan layak dipakai

Uji Konsistensi Internal angket minat Penelitian ini yang digunakan adalah $r_{x y}>0,3$. Hasil perhitungan konsitensi internal butir angket menunjukkan bahwa dari 20 butir pernyataan yang diuji cobakan ada 5 butir pernyataan yang tidak memenuhi kriteria yaitu butir soal nomor 5, 13, 17, 18, dan 20. Selain 5 butir pernyataan tersebut layak dipa-kai untuk angket minat belajar geografi.

Teknik analisis data pada penelitian ini melalui tiga tahap yaitu (1) uji prasyasarat analisis diantaranya adalah uji normalitas, uji homogenitas varians (2) tahap deskrisi data dan (3) uji hipotesis menggunakan analisis varian dua jalur.

Uji Normalitas digunakan untuk mengetahui apakah data sampel random berasal dari populasi yang berdistribusi normal. Uji yang digunakan adalah uji kolmogorofsmirnov dengan tingkat signifikansi $\alpha=0,05$. Rangkuman dari perhitungan data untuk uji normalitas, menunjukkan bahwa data hasil belajar berasal dari populasi yang berdistribusi normal yang ditunjukkan dengan nilai Asymp. Sig. (2-tailed) sebesar 0,694.Uji Homogenitas Varians.

Uji homogenitas varians yang digunakan adalah uji Levene's dengan tingkat signifikansi $\mathrm{a}=0,05$. Rangkuman hasil penelitian untuk uji homogenitas sebagai berikut:
Tabel 2. Uji homogenitas dengan Levene's Test of Equality of Error Variances ${ }^{\mathrm{a}}$

\begin{tabular}{|c|c|c|c|}
\hline $\mathbf{F}$ & df1 & df2 & Sig. \\
\hline, 525 & 5 & 43 &, 756 \\
\hline
\end{tabular}

Tabel 2 menunjukkan bahwa data amatan metode inkuiri dan problem-based learning maupun masing-masing kategori minat belajar memiliki varians yang sama pada uji homogenitas menunjukan nilai signifikan levene's test sebesar 0,756.

Berdasarkan analisis uji persyaratan menunjukkan bahwa sampel random, data amatan berasal dari populasi yang berdistribusi normal dan memiliki varians yang sama, dengan demikian analisis uji hipotesis dengan teknik analisis varians dapat dilanjutkan. Rangkuman hasil uji hipotesis dengan taraf signifikansi $\alpha=0,05$ diperoleh hasil bahwa:

Efek faktor metode (pembelajaran dengan metode inkuiri dan metode problembased learning) terhadap variabel terikat (hasil belajar) menunjukkan nilai probabilitas tingkat signifikan sebesar 0,071. Dikarenakan nilai probabilitas berada diatas tingkat signifikan sebesar 0,05 maka hipotesis ditolak, yang berarti tidak terdapat perbedaan yang siginifikan antara pembelajaran dengan metode inkuiri dan metode problem-based learning terhadap hasil belajar geografi. Dengan demikian hipotesis pertama yang menyatakan metode inkuiri lebih efektif daripada metode problem-based learning terhadap hasil belajar siswa tidak terbukti.

Efek faktor minat belajar (rendah, sedang dan tinggi) terhadap variabel terikat (hasil belajar) menunjukkan nilai probabilitas tingkat signifikan sebesar 0,304. Dikarenakan nilai probabilitas berada diatas tingkat signifikan sebesar 0,05 maka hipotesis ditolak, yang berarti tidak terdapat perbedaan yang siginifikan antara minat belajar rendah, sedang, dan tinggi terhadap hasil belajar geografi. Dengan demikian hipotesis kedua yang menyatakan bahwa siswa dengan minat tinggi memiliki hasil belajar lebih baik dibandingkan siswa dengan minat rendah dan sedang tidak terbukti.

Interaksi antara faktor metode dan minat belajar siswa terhadap hasil belajar geografi menunjukkan nilai probabilitas tingkat signifikan sebesar 0,938. Dikarenakan nilai probabilitas berada diatas tingkat signifikan 
sebesar 0,05 maka hipotesis ditolak, yang berarti interaksi dari metode dan minat belajar tidak berpengaruh siginifikan terhadap hasil belajar geografi. Dengan demikian hipotesis ketiga yang menyatakan bahwa terdapat interaksi antara metode pembelajaran dan minat dalam penerapan pendekatan saintifik dalam meningkatkah hasil belajar tidak terbukti

\section{Simpulan}

Berdasarkan analisis data dan pembahasan yang telah dilakukan maka dapat diambil kesimpulan sebagai berikut:

Pertama, metode pembelajaran inkuiri tidak lebih efektif dibandingkan dengan metode pembelajaran problem-based learning dalam meningkatkan hasil belajar geografi pada siswa di SMA Negeri Kabupaten Ngada.

Kedua, hasil belajar geografi pada siswa dengan minat belajar tinggi tidak lebih baik dibandingkan siswa dengan minat belajar sedang dan rendah pada siswa di SMA Negeri Kabupaten Ngada. Masing-masing metode pembelajaran tidak terdapat perbedaan dari tingkat minat belajar terhadap hasil belajar geografi yaitu: (a) pada metode inkuiri, hasil belajar geografi siswa dengan minat belajar tinggi tidak lebih baik dari siswa dengan minat belajar sedang dan hasil belajar geografi siswa dengan minat belajar sedang juga tidak lebih baik dari siswa dengan minat belajar rendah, dan (b) pada metode problem-based learning, hasil belajar geografi siswa dengan minat belajar tinggi tidak lebih baik dari siswa dengan minat belajar sedang dan hasil belajar geografi siswa dengan minat belajar sedang tidak lebih baik dari siswa dengan minat belajar rendah.

Masing-masing kategori minat belajar juga tidak terdapat perbedaan dari metode pembelajaran terhadap hasil belajar geografi yaitu: (a) pada tingkat minat belajar tinggi, hasil belajar siswa yang diajar dengan metode inkuiri tidak lebih baik daripada yang diajar dengan metode problem-based learning, (b) pada tingkat minat belajar sedang, hasil belajar siswa yang diajar dengan metode inkuiri tidak lebih baik daripada yang diajar dengan metode problem-based learning, (c) pada tingkat minat belajar rendah, hasil belajar siswa yang diajar dengan metode inkuiri tidak lebih baik daripada yang diajar dengan metode problem-based learning.

Ketiga, tidak terdapat interaksi antara metode dan minat dalam meningkatkan hasil belajar geografi di SMA Negeri Kabupaten Ngada, hal ini menunjukkan bahwa hasil belajar dengan metode inkuiri dan metode problem based-learning adalah sama saja dalam hubungannya meningkatkan hasil belajar.

Implikasi

Berdasarkan penelitian ini, penulis menyampaikan implikasi yang bermanfaat secara teoritis maupun praktis dalam upaya meningkatkan hasil belajar geografi siswa.

\section{Implikasi Teoritis.}

Implikasi dalam penelitian ini diperoleh hasil bahwa metode inkuiri dan metode problem-based learning sama-sama efektifnya. pengajar perlu diperdalam tentang teori pembelajaran inkuiri dan problem-based learning agar dalam pelaksanaannya lebih mudah dipahami siswa. Penggunaan metode inkuiri dan metode problem-based learning melalui minat belajar sama-sama menghasilkan hasil belajar yang baik, untuk itu perlu dikembangkan pembelajaran kedua metode tersebut kedepannya agar metode ini menjadi lebih baik.

\section{Implikasi Praktis.}

Sehubungan terbuktinya tidak ada perbedaan antara pembelajaran metode inkuiri dan metode problem-based learning maka diharapkan pihak sekolah dapat menerapkan kedua metode tersebut pada semua pokok bahasan. Kedua metode dapat menjadi salah satu alternatif dalam pemecahan masalah dalam proses pembelajaran yang dapat mengembangkan sikap percaya diri serta kreativitas belajar siswa. Proses pembelajaran dengan kedua metode tersebut dapat dilaksanakan secara optimal dalam mencapai tujuan pembelajaran, ada hal-hal yang perlu diperhatikan oleh pengajar, antara lain: (a)Perlu diberikan penjelasan mengenai prosedur pembelajaran metode inkuiri sejelas-jelasnya pada siswa, agar siswa dapat melakukan proses pembelajaran secara terarah dalam mencapai tujuan pembelajaran. (b) perlu menumbuhkan rasa percaya diri siswa dalam belajar kerjasama 
dan dengan teman-temannya. (c) diperlukan pengkondisian pembelajaran yang mendukung kegiatan siswa dalam belajar dan memecahkan permasalahan yang sedang dihadapi.

Saran

Agar hasil belajar geografi dapat ditingkatkan, maka disarankan: Kepada Guru diharapkan agar aktif memberikan pembelajaran melalui pemanfaatan model-model pembelajaran yang bervariatif, dan berdasarkan hasil penelitian ini guru dapat menggunakan model pembelajaran inkuiri maupun problem-based learning dalam proses pembelajaran khususnya pada mata pelajaran geografi karena dapat membuat siswa lebih aktif berpartisipasi dalam kegiatan pembelajaran serta pemahaman siswa dapat meningkat.

Guru harus selalu kreatif dalam menyusun rencana pembelajaran, penyelenggaraan pembelajaran, dan menyelenggarakan evaluasi yang tepat sehingga siswa tertarik dan akhirnya dapat meningkatkan hasil belajar geografi.

Kepada pihak sekolah metode pembelajaran inkuiri dan problem-based learning sebaiknya lebih sering digunakan dalam pembelajaran di kelas khususnya pada mata pelajaran geografi dan umumnya pada mata pelajaran yang lain. Terlebih karena sekolah sudah memiliki fasilitas yang memadai di setiap kelasnya sehingga dapat mendukung pembelajaran yang lebih bervariasi. Metode pembelajaran inkuiri dapat menjadi alternatif yang tepat sebagai upaya untuk menyajikan kegiatan pembelajaran yang bervariasi. Dengan bervariasinya pembelajaran maka akan meningkatkan keaktifan dan hasil belajar siswa.

Pihak sekolah memberikan kesempatan kepada para guru agar aktif mengikuti kegiatan-kegiatan yang sifatnya menambah pengetahuan baik dari materi maupun metode pembelajaran, dengan demikian kompetensi guru dalam mengajar makin baik dan dampaknya hasil belajar siswa juga meningkat.

\section{Daftar Pustaka}

Arends, R. (2007). Learning to teach belajar untuk mengajar. Yogyakarta: Pustaka belajar.

Johnson, A. P. (2010). Making connections in elementary and middle school social studies. United states of America: SAGE publications Ltd.

Candra, A., \& Masruri, M. (2015). Pengembangan multimedia interaktif dengan pendekatan saintifik untuk pembelajaran PKn SMP. Harmoni Sosial: Jurnal Pendidikan IPS, 2(2), 109-114. Available at: http://journal.uny.ac.id/index.php/hsjpi/a rticle/view/7662/6603

Celika, P., Onderb, F., \& Silaya, I. (2011). The effects of problem-based learning on the students' success in physics course. Procedia-Social and Behavioral Sciences $28656-660$

Daryanto. (2014). Pendekatan pembelajaran saintifik. Yogyakarta: Gava Gramedia.

Graaff, E \& Kolmos, A. (2003).

Characteristics of Problem-Based Learning. International Journals and of Several International Advisory Boards for Faculty Development Programmes and EU Programmes. 19, (5).

Gustin, G., \& Suharno, S. (2015). Evaluasi pembelajaran pendidikan pancasila dan kewarganegaraan dengan pendekatan saintifik. Harmoni Sosial: Jurnal Pendidikan IPS, 2(2), 144-157.

Available at: http://journal.uny.ac.id/index.php/hsjpi/a rticle/view/7666/6607

Hong \& Siegler, L. 2011. How Learning About Scientists' Struggles Influences Students' Interest and Learning in Physics. Journal of Educational Psychology. Advance online publication. doi: 10.1037/a0026224

Hughes. 2003. Learning \& Teaching Pengantar Psikologi pembelajaran modern. Bandung: Nuansa.

Dostál, J. 2015. The definition of the term "Inquiry-based instruction. International Journal of Instruction 8, (2).

Kementerian Pendidikan dan Kebudayaan. (2013). Materi pelatihan guru implementasi Kurikulum 2013. Jakarta: Kementerian Pendidikan dan Kebudayaan. 
Mulyasa, E. (2010). Menjadi guru profesional menciptakan pembelajaran kreatif dan menyenangkan. Bandung: Remaja Rosdakarya.

Nelva, R. (2010). Model pembelajaran atraktif untuk meningkatkan minat belajar siswa. Jurnal Penelitian Ilmu Pendidikan 3 (2) september hal 136-113.

Sani, R. A. (2014). Pembelajaran saintifik untuk implementasi Kurikulum 2013. Jakarta: Bumi Aksara.

School Is Easy Tutoring. 2016. The Importance of Interest in Learning, artikel. Diambil pada tanggal 9 juni 2016, dari https://www.schooliseasy.com/2014/03/i mportance-interest-in-learning/S.A,

Simsek, P. \& Kabapinar, F. (2010). The Effects of Inquiry-based Learning on Elementary Students' Conceptual Understanding of Matter, Scientific Process Skills Andscience Attitudes. Procedia Social and Behavioral Sciences. 2 (2010) 1190-1194.

Slameto. 2003. Belajar dan faktor faktor yang mempengaruhinya. Jakarta: Rineka Cipta.

Westwood, P. (2008). What Teacher Need to Know about Teaching Method. Australia: ACER Press. 